\title{
Insect Pest occurrence on Cultivated Amaranthus Spp in Benin City, Edo State, Nigeria
}

\section{${ }^{* 1}$ EZEH, AE; $*^{2}$ OGEDEGBE, AB.O; ${ }^{3}$ OGEDEGBE, SA}

\author{
${ }^{I}$ Department of Animal and Environmental Biology, Faculty of Life Sciences, University of Benin, Benin City, Edo State, Nigeria. \\ ${ }^{* 2}$ Department of Science Laboratory Technology, Faculty of Life Sciences, University of Benin, Benin City, Edo State, Nigeria. \\ ${ }^{3}$ Department of Crop Science, Faculty of Agriculture, University of Benin \\ *Corresponding Author: (e-mail: crestedsas_4good@yahoo.com)
}

\begin{abstract}
Amaranthus is one of those rare plants whose leaves are eaten as vegetables and seeds as cereal. Unfortunately, one of the major factors limiting the productivity of Amaranthus is the incidence of insect pests attack. The aim of this study was to determine the insect pest occurrence on cultivated Amaranths in Benin City, Nigeria. The experiment was conducted in the Agricultural farm of University of Benin, Edo State, Nigeria. Three varieties of Amaranth were used for this experiment, namely, Amaranthus cruentus (white-seeded), Amaranthus hybridus (red-seeded) and Amaranthus hybridus (black-seeded). The experimental design used was completely randomized design with three replicates, each replicate having nine plots. The result showed the diversity of insect pests associated with Amaranth. Insects found on Amaranth were classified into seven (7) orders, namely Coleoptera, Lepidoptera, Diptera, Hemiptera, Orthoptera, Hymenoptera and Mantodea; and eight (8) species. The species included Gasteroclisus rhomboidalis and Hypolixus sp. (Coleoptera); Hymenia recurvalis and Psara sp. (Lepidoptera); Liriomyza sp. (Diptera); Cletus sp. and Aspavia armigera (Hemiptera) and Zonocerus variegates (Orthoptera). Majority of the pests are defoliators, except Cletus sp. and Aspavia armigera that attack grains. The result also revealed that the period of pest occurrence is associated with Amaranth age. Knowledge from this study can be employed by Amaranth growers to ensure proper management of these insect pests. (C) JASEM
\end{abstract}

\section{http://dx.doi.org/10.4314/jasem.v19i2.22}

KEYWORDS: Insect, Pests, Amaranthus spp, Management.

\section{INTODUCTION}

Amaranthus spp are herbaceaous annual plants belonging to the family Amaranthaceae. It is one of those rare plants whose leaves are eaten as vegetables and seeds as cereal (Kauffman and Hass 1983). Amaranthus species is one of the plants often considered as the most important green leafy vegetable in Africa because it provides minerals and vitamins in the diets of many developing countries and could be used to circumvent the problem of malnutrition.Vegetable crop production in Africa, including Amaranthus, has been plagued with an array of factors such as poor farm input, poor cropping systems, incidence of pest and diseases as well as poor soil productivity status (Nwangburuke et al 2012a).

The agricultural significance of pests on crop plant is the damage they cause which reduces the quality or quantity (or both) of yield. Often the first manifestation of the presence of a pest or disease is in the appearance of the crop which may exhibit particular type of pest damage or disease symptoms (Hein, 2003)
There are two main types of crop damage caused by insect pests which is related to their mode of feeding (Hinks, 1976), the first is damage due to biting and chewing of plant materials. The groups of insects concerned are orthoptera (grasshoppers, locust, cricket), larvae of Lepidoptera (caterpillar), adult and larvae of many beetles (coleopteran) and other dipteran larvae (Sorensen, 1995). The second is damage due to sucking of the plant sap from the phloem or xylem system or from general tissues of foliage, roots or fruits. The main group of insects concerned is hemiptera (bugs) and the thysanoptera (thrips) (Sorensen 1995).

On Amaranthus spp, especially cultivated types, a wide diversity of insects have been recorded which infest the plant in varying levels of intensity and which exploded the plants in one way or another. Aragón et al. (1997) in a study located in the Valley of Tehuacán, Puebla, noticed that the species that cause damage to the Amaranth crop could be classified into three groups: the stem borers, the leaf eaters and the root pests. 
Okunlola et al, 2008, Richard, 1989 also stated that amaranths are susceptible to damage by foliar insect pests and disease such as aphids (Aphis spp) leaf worms (Spodoptera spp_ leaf roller (Sylepta derogata), leaf miners (Liriomyza spp), Spidermites (Tetranychins spp), stem boring weevils (Hypolixus haereus) bugs (Aspavia armigera)

Bugs can cause severe damage to flowering head and seeds particularly damaging to grain Amaranth when present in large numbers during critical seed fill stage. They are usually minor importance in vegetable Amaranth.

The traditional application of wood ash to dispel the insects is now often replaced by frequent applications of insecticides. Dales 1996 noted that the use of synthetic insecticides pose health risk and result in environmental pollution. Also Shmutterer, 2002 reported that the World Health Organization (WHO) had reported the poisoning of at least 3 million agricultural workers due to pesticide usage. They also noted that consumers of vegetables may be at risk from pesticide residues.

Sithananthan, (2004) and Losenge (2005) stated that over-reliance on organochlorides and organophosphates or their derivates as a control strategy for pest is facing resistance due to rising impact on the environment and health of human beings and their animals as a results of their persistence is soils and bioaccumulation. Losenge (2005) suggested that use of biological control agents, pesticides derived from judicious use or complete abstinence from persistent pesticides is the way forward in the management of insect pests.

The aim of this work is to investigate the Insect Pest occurrence on cultivated Amaranthus spp. This work would assist Agronomists and Entomologists to determine the type of insect pest associated with different stages/parts of Amaranth plant. Thus, ensure judicious use of right pesticide at the right time.

\section{MATERIALS AND METHODS}

This study was carried out in the experimental farm of Faculty of Agriculture, University of Benin, Benin City, Edo State Nigeria. Benin City is located at latitude $6^{\circ} 36^{\prime} \mathrm{N}$ and $6^{\circ} 19^{\prime} \mathrm{E}$. It has a tropical climate with clear cut of rainy and dry seasons (the rainy season lasts between April and November, reaching its peak in July and September while the dry season lasts between November and March. The area has a bimodal rainfall with mean annual rainfall of $1761.90 \mathrm{~mm}$ and a mean daily temperature of $26: 5^{\circ} \mathrm{C}$.
The experimental design used was completely randomized design (CRD) with three replications; Each replication had nine plots, forming a total of twenty-seven plots in the experiment. Three varieties of Amaranth (Amaranthus cruentus (white-seeded), Amaranthus hybridus (red seeded) and Amaranthus hybridus (black seeded) were employed. A plastic bowl of area $=170.76 \mathrm{~cm}^{2}$ represented a plot, forming a total plot area of $46055.52 \mathrm{~cm}^{2}$.

The seeds used for the experiment were obtained from Department of agronomy, faculty of Agriculture, University of Benin. Edo State Nigeria.The seeds of the Amaranth varieties were mixed with river sand in ratio of 1 part seed: 20 parts sand and appropriate amaranth varieties were broadcast on the corresponding soil.

Crops were thinned ten days after sowing to 12 plants/plot, at a spacing of $12 \mathrm{~cm} \times 12 \mathrm{~cm}$, the plants on each plot were searched visually and the insects on the plants were counted taken into consideration the population size of each insect species and the part of the plant the insects were found. A representative of each species was collected and taken to the laboratory for identification.

Materials used for collecting insect samples include sweep nets for flying insects, pair of forceps and hand picking for larvae and slow moving insects. They were deposited into polyethylene bags labeled with the following information: Collection date, number of each species and the part of the plant of which the insects were found. Immature leaf eating stages were transported in pots to cages and leaves of amaranth were provided as food in order to allow for continuation of their development until they reach adult stage.

The sampling period occurred in one day of every week for 3 months from February -April 2013, and records were taken for at least 2 hours from 9.00am 11.00 am hours, a repeat of the work was carried out from February - April 2014.

The data collected were subjected to analysis of variance (ANOVA) to test the significance of crop with insect occurrence using the Statistical Analysis System (SAS) software package version 9.00 (2000). The means were separated with the Least Significance Difference (LSD) method described by Steel et al., (1997).

$$
{ }^{*} \mathrm{EZEH}, \mathrm{AE} ; *^{2} \mathrm{OGEDEGBE}, \mathrm{AB} . \mathrm{O} ;{ }^{3} \mathrm{OGEDEGBE}, \mathrm{SA}
$$




\section{RESULT AND DISCUSSION}

The insects found on the Amaranth were identified and classified into seven (7) Orders and eight (8) species. The Order, Family, Scientific and Common name of these insects are listed in Table 1. Majority of the pests are defoliators, except Cletus species and Aspavia armigera that attack grains. Figures 1 shows the tri-weekly total in the insect abundance on
Amaranth varieties cultivated on the three nutrients. Table 2 shows the effect of age of crop on insect pest infestation of Amaranths. This depicts the relationship between insect occurrence with the age of Amaranth crop. The records show that week 3 had the lowest insect occurrence and that the insect abundance increases with the age of Amaranths,

Table 1: List of Insect species found on Amaranth plant

\begin{tabular}{|c|c|c|c|c|}
\hline Order & Family & Scientific name & Part of plant attacked & Abundance \\
\hline Coleoptera & Curculionidae & Gasteroclisus rhomboidalis & Leaves/Stem & 19 \\
\hline 10 & Coleoptera & Curculionidae Hypol & lixus $s p$ & Leaves/Stem \\
\hline Lepidoptera & Pyralidae & Hymenia recurvalis & Leaves & 26 \\
\hline Lepidoptera & Crambidae & Psara sp & Leaves & 3 \\
\hline Diptera & Agromyzidae & Liriomyza $s p$ & Leaves & 17 \\
\hline Hemiptera & Coreidae & Cletus $s p$ & Grains/Leaves & 58 \\
\hline Hemiptera & Pentatomidae & Aspavia armgera & Grains/Leaves & 1 \\
\hline Orthoptera & Pyrgomorphidae & Zonocerus variegatus & Leaves & 27 \\
\hline Hymenoptera & Formicidae & & Leaves & 7 \\
\hline Mantodea & Mantidae & & Leaves & 2 \\
\hline
\end{tabular}

Abundance $=$ Average individual per plant

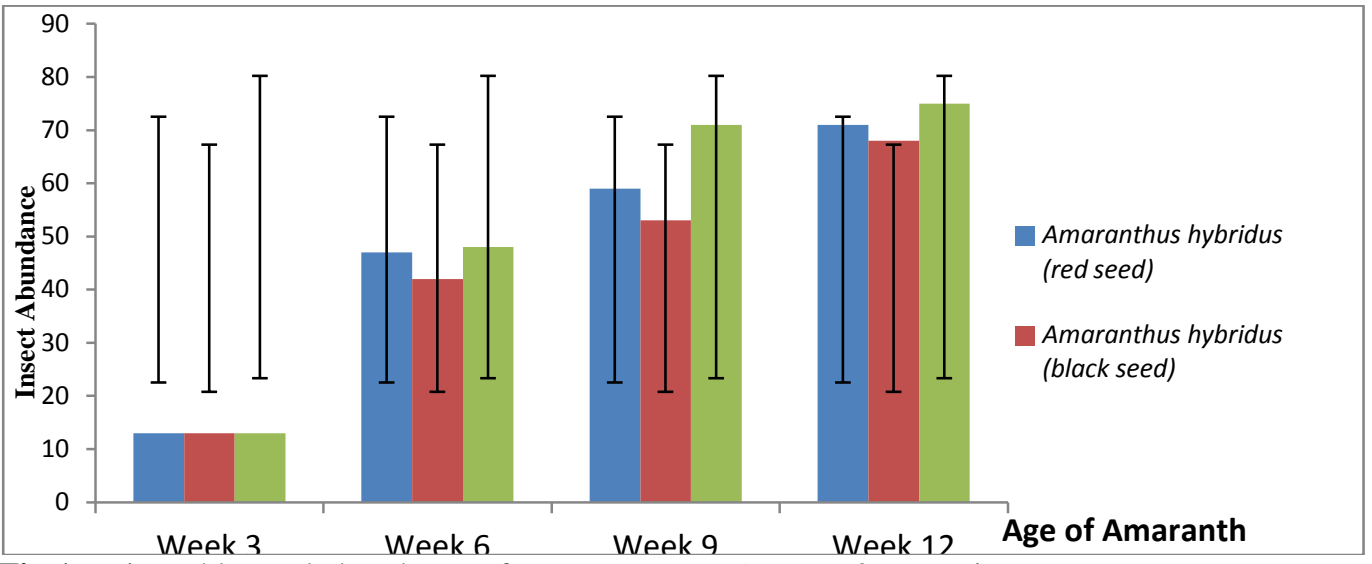

Fig 1: Tri weekly total abundance of Insect Pests on Amaranthus species

TABLE 2: Effect of Age of Crop on Insect Pest Infestation of Amaranths.

\begin{tabular}{|c|c|c|c|c|c|c|c|c|c|}
\hline Treatment & \multicolumn{8}{|c|}{ MEAN NO. OF INSECT PESTS/PLANT } & \multirow[b]{2}{*}{$\begin{array}{c}\text { Cletus } \\
\text { sp }\end{array}$} \\
\hline Variety (V) & Total & $\begin{array}{r}\text { Aspavia } \\
\text { armigera }\end{array}$ & $\begin{array}{r}\text { Psara } \\
\text { sp }\end{array}$ & $\begin{array}{c}\text { Liriomyza } \\
\text { sp }\end{array}$ & Hypolixus & $\begin{array}{l}\text { Gasterolisus } \\
\text { rhomboidalis }\end{array}$ & $\begin{array}{l}\text { Hymenia } \\
\text { recurvalis }\end{array}$ & $\begin{array}{l}\text { Zonocerus } \\
\text { variegatus }\end{array}$ & \\
\hline Week 3 & 0.47 & 0.00 & 0.0 & 0.13 & 0.00 & 0.00 & 0.30 & 0.00 & 0.00 \\
\hline Week 6 & 1.50 & 0.00 & 0.12 & 0.67 & 0.24 & 0.33 & 1.22 & 0.01 & 0.14 \\
\hline Week 9 & 4.23 & 0.02 & 0.09 & 0.45 & 0.31 & 0.57 & 0.35 & 0.90 & 1.54 \\
\hline Week 122.84 & 0.04 & 0.02 & 0.23 & & 0.17 & 0.38 & 0.13 & 0.57 & 1.30 \\
\hline Significance & $* *$ & $*$ & $*$ & $* *$ & $* *$ & $* *$ & $* *$ & $* *$ & $* *$ \\
\hline LSD & 0.19 & 0.01 & 0.05 & 0.09 & 0.07 & 0.10 & 0.10 & 0.07 & 0.15 \\
\hline
\end{tabular}

${ }^{*}$ EZEH, AE; *2 OGEDEGBE, AB.O; ${ }^{3}$ OGEDEGBE, SA 
Note: $* *=$ Highly Significance, $*=$ Significance, LSD $=$ Least Significance Difference.

The results from this study show the diversity in the number of insect species associated with Amaranth plant. Throughout the period of the survey, all insect species except Mantidae and Formicidae caused damage to the plant. These insects are therefore classified as pests (Wigglesworth, 2012).

This result concur wth the findings from similar survey carried out in different parts of Nigeria (Aderolu et al 2013, Akinlosotu 1977). Aderolu et al., (2013) reported Hymenia recurvalis as the most abundant Lepidopteran pest of Amaranth in Nigeria while Akinlosotu (1977) reported that Gasteroclisus rhomboidalis as the major pest of Amaranthus cruentus in Nigeria. From the results Cletus $s p$ recorded the highest occurrence on the Amaranth plant . This corresponds with the study carried out by Kagali et al (2013), in Kenya who reported that Cletus sp in the order Hemiptera was the insect with greatest number occurring in all the plots surveyed with $100 \%$ infestation. Other pests with high infestations are Zonocerus variegatus, Hymenia recurvalis, Gasteroclisus rhomboidalis and Liriomyza spp.

The result from this study also revealed a change in the population of insect pest with plant age with a high significance difference of $p<0.0001$. This concur with the findings of Freitas et al (2004) who through his study revealed that period of pest occurrence is associated with host plant age. Diperan pest and Lepidopteran pests occurred on the Amaranth at about 3 weeks after planting and reduced after week 6 . This was probably because the young leaves of these plants provides succulent sap which serves as a suitable shady breeding habitats for them especially Liriomyza and Hymenia larva which feeds and develop on Amaranth leaves.

The coleopteran pests and orthopteran pests infestation started at about 4 weeks after planting while Hemipteran pest started at about 6weeks after planting, these became more prevalent at later age of the plant. Studies by Robert et al (2013) in Kenya also suggested that age of plant have an effect on insect pest infestation. They observed that Hemipteran pest (Cletus $s p$ ) occurred mostly at the beginning of milking stage and the population increases as the grain matures.

This was also observed by Oke and Ofuya (2011), in their study on Amaranth in Ibadan, Nigeria. They observed that the population of Cletus $s p$ increases gradually from the start of milking stage to maturity with the highest population being recorded slightly before harvesting.

This indicates that farmers planting Amaranth for its vegetable can harvest the vegetable at about 45 weeks after planting without encountering serious pest damage on the vegetable, thus abating the use of pesticides while farmers planting Amaranth for its grain need to control Hemipteran pests (eg Cletus $s p$ and Aspavia armigera) at the beginning of the milking period which was observed to start at about 6 weeks after planting. This knowledge should be employed by Amaranth growers to ensure judicious use of pesticide which has been reported to cause several pesticide related complications and toxic residues in vegetables.

Also the use of Mantidae and Formicidae as biological control agents in the management of Amaranth insect pests should further be developed.

\section{REFERENCES}

Aderolu, I.A., Omooloye, A.A and Okelana, F.A. (2013). Occurrence, Abundance and Control of the Major Insect Pests Associated with Amaranths in Ibadan, Nigeria, journal of Entomology, Ornithology \& Herpetology 2:3-7.

Akinlosotu, T.A. (1977). A checklist of insects associated with local vegetables in Southwest Nigeria. Research Bulletin, IAR and T. Ife. 5:1823.

Aragón, G.A, Tapia-Rojas, A.M., Huerta-Sánchez, S.I.(1997). Insects associated with the Amaranth crop Amaranthus hypocondriacus L. (Amaranthaceae) in the Tehuacán Valley, Puebla, Mexico. Folia Entomology, Mexico, 100: 33-43.

Dales. M.J. (1996). A review of plant materials used for controlling insect pests of stored products. NRI, Chatham Maritime, UK.

Freitas, F. A., Zanuncio, T. V., Zanuncio, J. C., Conceição, P.M., Fialho, M. C. Q. and Bernardino A. S.(2005) Effect of plant age, temperature and rainfall on Lepidoptera insect pests collected with light traps in a Eucalyptus grandis plantation in Brazil. Ann. For. Sci, 62 (1), 85-90.

$$
{ }^{* 1} \text { EZEH, AE; *2OGEDEGBE, AB.O; }{ }^{3} O G E D E G B E, S A
$$


Hein, G.L. (2003). Insect management. United States Development for Agriculture. 268pp

Hinks C.F. (1976). Biosystematics of the genum Euxoa Lepidoptera: Noctuidae). V.Rearing procedures, and life cycles of 36 species. AGRIS, 108(12): 1345-1357.

Kauffman. C.S., Haas, P.W, (1983). Grain amaranth: A crop with low water requirements and high nutritional value. Environmentally Sound Agriculture. W.Lo Keretz: 299pp.

Kigali, R.N., Kioko, E.N, Osiemo, Z, Muya, S. Catherine, W. (2013). Insect abundance and diversity on cultivated Amaranthus (Amaranthadeae) in Meru County Kenya. American International Journal of Contemporary Research, 3:7-9.

Losenge, T. (2005). Insect pest management for plant health: Population dynamics of Thrips in pure and mixed cropping. Proceedings of 5th Horticultural Seminar on Sustainable Horticultural production in the Tropics. Njoro, Kenya: Horticultural Association of Kenya. 158 pp.

Nwangburuka, C.C., Olawuyi, O.J., Oyekale, K., Ogunwenmo, K.O., Denton, O.A and Nwankwo,E .(2012a). Growth and yield response of $C$. Olitorius to Treatments of arbuscular mycorrhiza (AM),Poultry manure (PM), Combination of AM-PM and inorganic fertilizer (NPK). Advances of Applied Science Research. 3(3):1466-1471.

Oke, O.A and T.I. Ofuya (2011). Relationship between population of Cletus fuscescens (Hemiptera:Coriedae) planting dates, Lines and grains Amaranth (Amaranthus spp) phenology. Journal of Entomology, 8: 566-573
Okunlola, A.I., Ofuya, T.I. and Aladesanwa, R.D. (2008). Efficacy of plant extracts on major insect pests of selected leaf vegetables in South Western Nigeria. Agricultural Journal, 3:181184.

Richard, R.W. (1989). Studies of insects feeding on grain Amaranth in the Mid West. Journal of the Kansas Entomological Society. 62(4):440-448

Schmutterer, H (2002). The Neem Tree, Azadirachta indica A. Juss and Othermeliaceous Plants Sources of Inuque Natural Products for Integrated Pest Management, Medicine and Other Purposes. Neem foundation, Mumbai, India, 892pp.

Sithanantham, S.M., Matoka, M., Maundu, M., Jakari and Agomg S. G. (2004). Integrated crop protection research for sustainable production of Indigenous vegetable crops in Eastern Africa. Proceedings of $4^{\text {th }}$ Horticultural Seminar on Sustainable Horticultural production in the Tropics. Njoro, Kenya: Horticultural Association of Kenya 319pp.

Sorensen K.A. (1995). Insect Pest of Vegetables. North Carolina Agricultural Extension Service 404pp.

Wigglesworth,V.B.(2012).Insect.Availableat:http://w ww.britannica.com/EBchecked/topic/28901/inse ct.

\footnotetext{
${ }^{*}$ EZEH, AE; *2OGEDEGBE, AB.O; ${ }^{3} O G E D E G B E, S A$
} 